\title{
NIGERIA FOREIGN POLICY THRUST: A COMPARATIVE ANALYSIS OF PRESIDENT
}

https://doi.org/10.47743/jopafl-2021-22-01

\author{
Benedict Ogheneakpoje IGHOSHEMU \\ Department of Political Science, Delta State University, \\ Abraka, Nigeria \\ ominiapere@gmail.com
}

\begin{abstract}
Foreign Policy is a set of tools or activities developed by states to drive its interest in the international system, internal and external environment, and the personality of the leader usually influence the country's policy articulation and implementation. Nigeria foreign policy, like other countries of the world is all about the projection, promotion, protection, realization and advancement of its national interest. This paper attempts a comparative analysis of the foreign policy thrust of President Olusegun Obasanjo democratic civilian Administration from 1999-2007 and that of President Muhammadu Buhari's democratic civilian Administration from 2015 till date. The work focused on the strength of Nigeria foreign policy and gains in the period under review. The choice of both Administrations for comparison becomes necessary, as both Presidents and leaders had formerly ruled the entity Nigeria as military heads of state. The paper examines both administration efforts in Nigeria foreign policy formulation and implementation, using secondary data scooped from books, journals, newspapers, magazines and internet materials. Descriptive analytical method was engaged using international cooperation theory in the discourse. Findings showed that Obasanjo marked his policies with practical actions while Buhari match his policies with non challant approach. The paper concludes that the leadership role as well as the domestic and external environment of both regimes account for the continous agains and the changes experienced in Nigeria foreign policy in both regimes.
\end{abstract}

Keywords: Foreign Policy, National interest, International relations, formulation, implementation.

\section{Introduction}

The word is now a global village hence the evaluation of Nigeria's foreign policy is imperative to ensure that the country's domestic and national interests are vigorously pursued within the International political system to promote our developmental goals as a nation. We cannot ignore how affairs around the world affect our internal environment, as the saying goes, "when America coughs the world shakes". Nigeria’s relationship with the international community started long before independence in 1960, under the colonial government, during which dependent Nigeria had no separate foreign policy outside of the British (Chibundu, 2009). During this time, the interest of Her Majesty, the Queen of England was the interest of the colonial Nigeria. The British colonial government, through its Governor-general administered Nigeria's foreign relations, which manifested in several ways, including the control of international trade, determination of import and export duties for Nigerians, the use of British colonial offices in other countries as bases for carrying on with external relations, sending of Nigerian soldiers to fight in the battle of Burma during the first world war, among other developments (Chibundu, 2009). On attainment of independence, the first distinct phase of Nigeria's foreign policy was the Balewa era, from October 1960 to January 1966. In their stock-taking and analyses of the outlook of Nigeria's foreign policy, King (1998), Fawole (2003) and Saliu (2007), reached a 
consensus that the basic principles of Nigeria's foreign policy can be summarized as follows:

- $\quad$ Non alignment with any of the then existing ideological and military power blocs especially NATO and Warsaw Pact during the world war;

- $\quad$ Respect for the legal equality, political independence sovereignty and territorial integrity of all states;

- $\quad$ Respect for the doctrine of non-interference in the domestic affairs off all other states;

- $\quad$ Seeking membership of both continental and global multilateral organizations for their functional importance to Nigeria; and Africa as the centre piece of Nigeria's external relation.

These principles constitute the Nigeria foreign policies with other countries of the world since independence. King (1998) posits that Nigeria foreign policy is rooted in the basic principles that have guided its relations with other countries. They are geared toward protecting and advancing Nigeria's national interest. Every government has accepted their validity, although the style and vigour with which each pursued them have differed significantly. King (1998) further assert that, all of these five principles provide a basis for formulating, executing, and justifying specific foreign policy objectives and the actions taken to achieve them. They constitute guidelines that the interested public may use to evaluate particular foreign policy behaviour. Upon Nigeria's return to democratic civilian government in 1999, the elected President Olusegun Obasanjo came with a new direction and style in Nigeria's foreign policy drive in reaction to existing domestic situation and international image of the country. He was motivated by the wave of globalization policy of restructuring and reformulate Nigeria foreign policy objectives (Ukwuije, 2015). The administration embarked on foreign trips which took President Obasanjo to several parts of the world. "The resort to frequent traveling by the President was all he needed to repackage Nigeria for external consumption” Saliu, (2007.P 406). It is on this note that the paper examines comparatively, Obasanjo and Buhari foreign Policies when in government as democratic Presidents.

\section{Objectives and research questions}

The general objective of the study is to critically compare the foreign policy objectives of Obasanjo and Buhari democratic administration.

\section{Research Questions}

The following research questions will guide the study.

i. $\quad$ What are the benefits of both administrations shuttle diplomacy to Nigerians?

How did the democratic administration of Obasanjo and Buhari economic diplomacy impacted on the citizens of Nigeria?

Has the administration of Obasanjo and Buhari leadership style have any influence on national interest of the country?

\section{Literature review and theoritical frame work}

Conceptual discourse. Concept of foreign policy 
Foreign policy basically is a programme of decisions and actions of a state in relation to its external environment designed to achieve a state's long and short term objective. By extension a country's domestic environment shapes the decision of its foreign policy. Morgenthau, (1966), tells us that "all foreign policy is a struggle for the minds of men”. George Modelski as cited in Bojang, A.S (2018), defines foreign policy as "the system of activities evolved by communities for changing the behavior of other states and for adjusting their own activities to the international environment”. Foreign policy must throw light on the ways states attempt to change and succeed in changing the behaviour of other states activities. Holsti, K.J (1972), view foreign policy as "the actions of a state towards the external environment and the condition usually domestic under which these actions are formulated. Wallace, (1971), posits that national survival and national security, the next most crucial use of foreign policy is economic development. Hence he asserts that most government pursue economic goals as major foreign policy objective. The pursuit of trading advantages the advancement and protection of foreign investment, the acquisition of materials, equipment and technology information for their domestic economy.

One thing that is clear from these assertions is that political leaders do prioritize the objectives they pursue through their foreign policies. President Olusegun Obasanjo, a onetime military head of state, democratically elected as civilian President in May 1999, focused on the following on Nigeria foreign policy:

- $\quad$ To re-integrate Nigeria into the mainstream of the international community.

- $\quad$ To restore Nigeria image in the international community.

- $\quad$ To attract foreign investment to Nigeria.

- $\quad$ To recover stolen public funds stashed in foreign bank accounts.

- $\quad$ To secure debt relief or outright debt cancellation for the country.

- $\quad$ To reduce to the barest minimum Nigeria's international financial commitment especially in Africa

- $\quad$ To strengthen Nigeria's bilateral and multilateral cooperation with other countries for the purpose of reaping economic benefits.

These directional changes of President Obasanjo's second entry in 1999 in his foreign policy thrust, made him to focus on the triple drive objectives of shuttle, economic and domestic diplomacies.

\section{Concept of Shuttle Diplomacy}

Diplomacy is one of the concepts that is best conceptualized through a consideration of its usage rather than attempting to arrest or capture a precise, fixed or authoritative meaning. Diplomacy is derived from the Greek word “diploma” denoting a folded document that contains the official hand writing and the idea of credentials confirming the claims of the bearer (Bajang, 2018). There is no consensus among scholars on the exact meaning of diplomacy. Osagie, (2007), observes that, diplomacy in the popular sense means the employment of fact, shrewdness and skill in any negotiation or transition. He went further to say that it is an application of fact and intelligence in international policies through negotiation, persuasion and compromise. Asobie, (2002), define diplomacy as management of international relations by negotiation. Bajang, (2018), viewed diplomacy as the application of intelligence and tactics to the conduct of official relations between the governments of independent states. The word shuttle Diplomacy is 
said to have emerged from Henry Kissinger's efforts in the Middle East in the early 1970s. He flew back and front between Middle Eastern capitals for months in an effort to bring about peace after the 1973 Arab-Israeli war. Fey and Ramsey (2010) assert that shuttle Diplomacy, "involves the intermediary meeting with each side in turn and relying in those discussions to progress towards a solution”. Akinterinwa, (2004), perceived shuttle diplomacy of Obasanjo to be a deal of foreign policy for promoting national objectives. Osagie (2007), noted that shuttle diplomacy was embarked upon to enable Nigeria reintegrate in to the comity of nation after being isolate.

The Politics behind shuttle diplomacy is primarily based on the use of a third party to convey information back and front between the parties, serving as a reliable means of communication less susceptible to the grandstanding of Face to Face or media based communication. The researcher in the paper, sees shuttle diplomacy as the foreign travels of the Fourth Republic presidents, and as a tool only for re-building Nigeria's foreign image and fine tuning the international economic environment of the nation for securing debt relief for Nigeria and for the investment/capital objectives of the Nigeria foreign policy, and the repatriation of looted funds by Nigerians while in public offices. The shuttle diplomacy of the Obasanjo administration is in line with the foreign policy objectives in the 1999 constitution Chapter 11, Section 19. Obasanjo's civilian administration on assumption of office as democratically elected president of the Federal Republic of Nigeria, accepted the task before him as that of bringing Nigeria out of her dead-end by consolidating democracy at home, respecting fundamental human rights and encouraging Liberal economic reforms, good governance and transparency with a view to boosting Nigeria image by reassuring the rest of the world that Nigeria was truly back on track Olasupo (2015). He under took foreign trips on regular basis, there is basically no major country that President Obasanjo did not visit during his tenure. He was bent on taking Nigeria out of the recluse of General Abacha's years. President Olusegun Obasanjo shuttle diplomacy was a vital instrument for foreign bilateral and multilateral collaboration for sustainable development and peaceful co-existence in the West Africa sub-region as well as with other countries of the world. Before 1999, Nigeria external debt was 27,008 billion dollars which present Nigeria as the highest debted country in Africa (CBN, 2002) and the country was spending 3 billion dollars yearly on debt servicing. Obasanjo shuttle diplomacy, went on the drive for foreign direct investment, campaign for cancellation of the Nation's debt and a cutting edge economic diplomacy to tackle the financial problems of the country. His foreign trips woo prospective investors to Nigeria and established high diplomatic contacts with leaders of Nigeria's creditors. The Olusegun Obasanjo shuttle diplomacy, helped Nigeria to be able to secure debt pardon from Paris and London clubs to the tune of 18 billion dollars and Nigeria foreign reserves that is 2 billion dollars at the point of his entry 1999, rose to 43 billion dollars while leaving office in 2007, it also helped to chart the cause for debt release for the nation by foreign creditors and to repatriate stolen money by public office holders back to the country (Olasupo, 2015).

\section{Obasanjo Economic Diplomacy}

The political and Social-economic situation in Nigeria on the return to democracy in 1999 creates an opportunity for economic renewal and an associated broader base for economic growth, foreign direct Investment and development. It was in view of this and 
many social political and economic abnormalities caused by the past military regimes that shape and defined the techniques, modalities and approach, employed by the civilian administration of President Obasanjo. He made diplomatic moves to redeem the battered and shattered image of Nigeria which were results of the unending transition to democracy which cumulated to the June 1993 annulment of election, Increase in the Abuse of Human rights and regular killing of Innocent Citizens (Ken-Saro-Wiwa and other Ogoni activists). This led to the imposition of International Sanctions on Nigeria as a result of military Involvement in politics. Nwachukwu cited in Ofose, (2014) in his words noted. Nigeria's Image attained it lowest ebb during the years of Abacha's misrule. General Abacha's poor administration, one could say with the benefit of hindsight, disastrous political decisionmaking during his leadership, contributed to the production of the most negative image that Nigeria had ever had. By 1995, Abacha's administration committed its greatest and gravest mistake. After Summary trial, Ken Saro-Wiwa and Eight other Ogoni activists were executed. International condemnation soon followed. Many countries, decided to internationally shy away from interaction with Nigeria. Abacha's Nigeria lost all respect and consideration in International politics, and the severity of the Ogoni activists execution led to countries' withdrawal of their ambassadors and head of mission and some closed down their diplomatic mission in Nigeria.

President Obasanjo on assumption as civilian President, was faced with the immediate challenge on how to transform Nigeria from a Pariah state, shunned and treated with contempt by the international community to a respectable and responsible nation, contributing its quota in making the world a safe and healthy place for all. Obasanjo therefore was bent on reintegrating Nigeria into the global economy and politics.

In his own words in Abuja, on May 29, 1999, President Obasanjo left no one in doubt about the thrust of his foreign policy and his intention to return Nigeria to the centre stage of global politics. Nigeria once a respected country and key player in international bodies became a Pariah nation. We shall pursue a dynamic foreign policy to promote friendly relations with all nations and will continue to play a constructive role in the United Nations (UN) and Organization of Africa Unity (OAU) now African Union (AU) and other international bodies. We shall continue to honour existing agreement between Nigeria and other countries. It is our firm resolves to restore Nigeria to her position in the comity of nations (Obasanjo, 1999). In pursuit of his foreign policy goals, President Olusegun Obasanjo in 1999, noted that Nigeria external debt was 27, 008 billion dollars, presenting Nigeria as the highest indebted Country in Africa (CBN, 2002) and the country was spending 3 billion dollars every year to service debts. To tackle the problem of huge debts Obasanjo went on Direct Investment drive, the campaign for the cancellation of the country's debt and a cutting edge Economic Diplomacy. This resulted in debt pardons from the Paris and London clubs amounting to 18 billion dollars and Nigeria foreign reserves rose from 2 billion dollars in 1999 to 43 billion dollars while leaving office in 2007 (Olasupo,2015). The new administration resuscitation of the economy for the well-being of the Nigeria people, repatriation of ill-gotten wealth of the previous regimes was also articulated.

For his Economic diplomacy, President Obasanjo was instrumental in gathering Africa leaders to work toward establishing a code of conduct in economic and political reforms that would satisfy the conditions and expectations of Western donors. At the June 2001 G8 Summit in Genoa, Italy, Obasanjo was one of the four leading African Heads of 
state to unveil an African initiated plan for the New Partnership for Africa's Development (NEPAD) and African Peer Review Mechanism (APRM) Osagie (2007). President Obasanjo made Nigeria's Presence felt with his several trips abroad to attend sessions of the United Nation (UN); Organization of Petroleum Exporting Countries (OPEC); Group 77 (G77); World Bank, International Monetary fund (IMF); World Economic Forum (WEF); Group 8 (G8); United Nations Educational Scientific and cultural organization (UNESCO); Commonwealth Organization; African Union (AU); Economic Community of West African States (ECOWAS); and other organizations to better economic situations already battered by previous administrations.

The administration targeted at investment promotion in which Nigeria was repackaged for Export - to create awareness of investment opportunities, he brought back several investors to Nigeria. China, Germany, Japan, Denmark, France, Canada, Abdulai, (2007:17). Greece, Russia, Norway, Poland, Spain, Italy, Switzerland and Israel also established bilateral investment relation with Nigeria during this period (NIPC Annual Report, 2006; CBN draft annual report ). The administration also encouraged Regional Economic Integration, the West African Gas Pipeline project (WAPCO) which is expected when completed to supply Natural Gas to Benin-Republic, Ghana, Togo and Cote d'Ivore in the West Africa sub region were embarked upon.

\section{Obasanjo Domestic Diplomacy}

Domestic diplomacy which is National interest as a concept can be traced back to Italy in the 16th and 17th centuries England. (http://fletcher.tufts.edu/research/2004/shembi-Rozetapdf). National interest broadly conceived is a guide to formulation of foreign policy. It is not an end in itself but a means to an end. It is a method of reaching a goal and in formulating such goals, core values and national ethos must be considered. The central role that value plays in defining national/domestic interest has been underscored by Northedge, F.S. (1974(ed)). According to him "value describes the inner element brought to bear on decision makers upon the process of making decisions”. The Obasanjo Olusegun civilian administration was targeted at economic and shuttle diplomacy as a strategies to redeem Nigeria's image and facilitate National development. His trips saw him having face to face discussions with Nigeria citizens in foreign lands (countries) seeking Nigerians at home and in diaspora to be involved in the development effort of the government economically and politically. This made his administration hang more in his second coming as a civilian President on citizens centric than his earlier administration of Afro-centrism that is why the policy as espoused by Ojomadueke, the then minister of foreign affairs in 2007, centered on reciprocity, implying that the manner in which Nigerians are treated by a particular country should determine the manner in which Nigeria should treat the citizens of that country (Agbu, 2009). Given the fact that foreign policy is an off shoot of domestic public policy, a stable economic and political economy is crucial to the actualization of foreign policy in the international arena (Ukwuije, 2015). Since 1999 Nigeria has been faced with multiple crises resulting from communal and religious-based violence, resource activism which has taken the form of militancy, and fluctuations in global oil prices, thus leading to political and economic instability (Abdul, Ibrahim, 2013 pp.40). The Obasanjo administration at the beginning promised the nation to improve the electricity sector that has been epileptic, 
tackle corruption and insecurity that was growing in all regions of the country. In the north the Islamic sect (Boko Haram); The east, the Igbo agitation for secession by the Indigenous People of Biafra (IPOB); and in the south the Niger Delta agitators for resource control due to neglect by the state and the multinational oil companies exploring and exploiting crude oil from the region. All of these were attempted, no significant result were recorded. In order to avert looming nationwide black out, he proposed to connect a total of 2,659mw of space capacity with his team to the National grid through the Oil Mineral Producing Area Development Commission (OMPADEC), Aluminum Smelting Company of Nigeria (ALSCON), Enron, Turbine system, Eagle energy and swede power sources (Olasupo, 2015). In Obasanjo's domestic policy, road construction, industries, citizens interest, employment, tackling of corruption and insecurity, improved health and education of the citizens, infrastructure were all articulated, much was achieved compared to that of Buhari civilian administration whose foreign direct investment on infrastructure is huge on the media andcitizens are yet to feel the impact. Much had not been achieved by the Buhari administration as a result of insecurity facing the nation under his watch.

\section{Buhari Shuttle Diplomacy}

President Muhammadu Buhari's administration when compared with Obasanjo's administration, there was no much difference, as both administration embark on debt recovery and image laundry as part of their shuttle diplomacy. On assumption of office in 2015 May, after the general election, President Buhari like President Obasanjo embarked on foreign tour of countries to bring Nigerians to the comity of nations and to improve relations with Nigeria's neighbours in order to jointly fight the menance of Boko Haram terrorist group that had brought bad name to the country. The Buhari administration partnered with United States of America (USA) and other world powers to support the Nigeria government in the fight against Boko Haram terrorist by aiding the Nation with the much needed manpower and intelligence. Buhari's travels to neighbouring Niger Republic, Benin Republic and Cameroon resulted in the entry for the multinational Joint tasks force to tackle the Boko Haram terrorist, and the relocation of the Multinational Joint Task Force headquarters from Nigeria to N'Djamena in Chad and appointing a Nigerian as the Commander of the Multinational Joint Task Force (MNJTF). This diplomatic relations between these ECOWAS countries helped to curtail the insurgent activities. His travels led to the improvement of relations with China in order to foster Economic development through provision of needed infrastructure. President Buhari Shuttle Diplomacy helped Nigeria to foster relations with the United State of America, China and the ECOWAS Countries, thereby helping Nigeria to fight Corruption which resulted to the US department of Justice (DOP) for the forfeiture of 144 million dollars, which was the proceeds, of corruption by Nigeria's former minister of Petroleum Diezani Alison-Madueke (Bello, Dutse and Othman, 2017). Buhari's foreign travels, his personality and his campaign promises of tackling Boko Haram terrorism and countering violent extremism, fighting corruption and improving the nation's economy were practically demonstrated on his entry to governance in his Shuttle Diplomacy just like the Obasanjo Administration.

\section{Buhari Economic Diplomacy}

Economic diplomacy of President Muhammadu Buhari unlike his predecessor, he was able to improve relations between Nigeria and the United States which has led to 
improving collaboration in the fight against Boko Haram and corruption resulting in the repatriation of stolen money back to the country and multilateral cooperation to fight insurgency of Boko Haram. The Buhari administration hinged his campaign promises on three cardinal points of combating Terrorism, fighting corruption and improving the economy. He improved relations with her neighbours in order to jointly fight Boko Haram which has assumed multinational or transnational dimension, partner with America and other world powers to support the government in order to fight terrorism by providing needed manpower and intelligence and more importantly the improvement of the economy and fighting corruption. He also improved relations with china in order to foster economic development through the provision of needed infrastructure. President Buhari administration barely one year after assuming office, visited China to solidify both countries trade, diplomatic and economic relations. This visit led to the signing of a frame work to enhance infrastructural development. Reform Commission of China and the Ministry of Industry, Trade and Investment of Nigeria, Technology and Scientific cooperation between both countries were entered into. In the visit, a number of loans were granted especially to finance the deficit of 2016 budget, infrastructure loan for trains, among others (Bello, Dutse and Othman 2017). The railway project by the Buhari administration was aimed at solving the infrastructural deficit in the country, also provides needed jobs for the populace and to stimulate the economy. The trade relations between Nigeria and China in just first half of 2016 has stood at $\$ 6.4$ billion (Bello, Dutse and Othman 2017).It has provided the Nigeria State with the needed funds to cushion the effect of infrastructural deficit and the nation's needed foreign direct investments.

Figure 1. Showing Infrastructural Project Agreement Signed Between China and Buhari Administration

\begin{tabular}{|l|l|l|}
\hline S/No & Project Worth & Projects \\
\hline 1 & \$1.231 billion & Lagos-Kano, modernization project Lagos-Ibadan segment \\
\hline & \$1.146 billion & Lagos-Kano railway modernization project, Kano-Kaduna segment \\
\hline & \$3.474 billion & Lagos-Calabar coastal rail project \\
\hline & \$6.1 billion & Ibadan-Ilorin-Minna-Kaduna-Kano line \\
\hline & \$1.4 billion & Lagos-Ibadan railway project \\
\hline & \$15 billion & Agricultural development \\
\hline & \$478 million & Dangote group cement project \\
\hline & \$55 million & Construction of 300 megawatts solar power in Shiroro, Niger State \\
\hline & \$1 billion & Greenfield expressway for Abuja-Ibadan-Lagos \\
\hline & \$250 billion & Ultra-modern 27 storey high rise complex \\
\hline & \$1 billion & Hi-tech industrial park in Ogun-Guangdong. Free trade zone \\
\hline & \$200 million & Construction of two 500mt/day float gas facilities \\
\hline & $\$ 363$ million & Comprehensive farm and downstream industrial park \\
\hline & $\$ 500$ million & Project for the provision of television broadcast equipment \\
\hline & \$25 million & Facility for production of pre-paid smart meters \\
\hline
\end{tabular}

Source: http://www.nta.ng/news/investment/20160410

\section{Buhari Domestic Diplomacy}

Buhari domestic diplomacy as earlier stated, it is observed that the subsisting domestic milieu on the Foreign Policy behavior of Buhari administration. President Buhari 
promised, during his compaign to tackle three major challenges facing the country, which include insecurity, corruption and dwinding economy. It is however, noteworthy that Nigeria's domestic problems are not limited to the ones stated. Some others as indicated by Akinterinwa include "intermittent polarization and instability, high level of unemployment and poverty, mono-cultural economy and low industrial and agricultural productivity......, the problem of institutional corruption, declining quality of education and ethical standard, as well as infrastructural deficit”. In all of these, the Buhari administration deed little or nothing, in addressing the issues of insecurity, corruption, unemployment, and educational decline in the country. People leave in fear of been killed or kidnapped, with high rate of insecurity, poverty and unemployment. The economy is of no better with high rate of inflation of goods and services by the day, there by breeding high rate of corruption in the country.

\section{Theoretical Framework}

This study is anchored on international cooperation theory. This theory emerged and evolved over the past few decades as a cornerstone of international relations. Thucydides discussed diplomacy treaties and alliances over two thousand years ago. Yet the study of international cooperation is surprisingly new. International cooperation theory is traditionally defined as occurring "when actors adjust their behaviours to the actual or anticipated preferences of others, through a process of policy coordination” (Milner, 1992, P.467 citing Keohane 1984). The concept of cooperation as we currently understand it crystallized in the early 1980s (Taylor, 1976, in Axelrod, 1981; 1984), as coordinating behaviour of independent and possibly selfish actors that benefits them all. Individual selfishness need not impede cooperation of institutions or interdependence where individual welfare depends on others' behaviour. Cooperation requires neither altruism nor government both of which are often in short supply at the international level. This definition of international cooperation is general in terms of both actors and issues. Cooperation occurs not only among individuals but also among collective entities, including forms, political parties, ethnic organizations, terrorist groups and nation states. Although, information and communications technology, often define international cooperation in terms of states. It can also involve other actors especially inter-governmental organizations (IGOs) and nongovernmental organization (NGOs). These diverse actors cooperate for different objectives across a wide range of issues area. IGOs work with states to combat global environmental problems; firms collude to monopolize markets, NGOs campaign to save the whales and so on. Finally, international cooperation is not always a good thing, at least from the perspective of those excluded or targeted. For example, International sanctions involved cooperation against target countries (Drazner, 1999), and commodity cartels often harm consumer states. It is a nation tool to strengthen, share and accelerate development within and across regions. It involves creating, adapting, transferring and sharing knowledge and experiences to achieve a common goal or benefits.

\section{Research method}

The researcher adopted time series research design. The time series research design involves a careful observation of a phenomenon over a specific period of time, while 
attributing changes in the phenomenon to casual events (Campbell \& Stanley, 1963). The study took historical account of the civilian regime of Obasanjo comparing it with that of Buhari, both as civilian Presidents of Nigeria and one time military heads of state. Data were derived from secondary sources involving the use of journals, newspapers, official, organized documents, textbooks, and internet materials. Descriptive method was used in the analysis of data collected.

\section{Data presentation, analysis and discussion of findings}

What are the benefits of both Administrations in their Shuttle Diplomacy to Nigerians?

The inauguration of chief Olusegun Obasanjo in May 1999 as elected President of the Federal Republic of Nigeria marked a watershed in the nation state's International image rating. Since independence in 1960, the Nigerian state had been enmeshed in long years of military rule leading to an apparent plummet of its international image- a phenomenon which reached its lowest point bringing Nigeria to the fringes of Pariah state at the brinks of democratic governance in 1999. Nigerians would prefer to forget the events of the Abacha regime which inflicted gratuitous and wanton pains on them and forced many Nigerians to seek Asylum abroad with those unable to travel forming various coalition movements in opposition to the draconic Junta. Sanubi F.A \&Oke, C.T.A (2017) During Abacha regime people lived in social anguish, vicious poverty and economic misery. Citizens who critises the government are marked and targeted for summary elimination. The period also witnessed, Interalia, the gruesome murder of the environmental rights activist, Ken Saro-wiwa and nine others of his Ogoni Kinsmen. The international community slamed the nation with economic and military sanctions including travel bans on top military personnel and their family members. Sanubi F.A. \& Ole, C.I.A (2017). On assumption of office in May 1999, Obasanjo embarked on foreign trips, he visited major countries in the world to lauder Nigeria battered image. Within 168 weeks in office he made over 103 foreign trips Ezeife (2003). He was able to build bilateral and multilateral relations among and between various counties of the world, Ezeife, (2003) reintegrating Nigeria into the international community leading to London and Paris club pardonings Nigeria debt amounting to \$18 billion dollars. Similarly, Muhammadu Buhari who over thrown democratically elected government in 1983, chose to follow the foreign policy of Murtala /Obasanjo military government which was radical in nature. Buhari second coming as an elected President of Nigeria in 2015, also hinged on improving relations with neighbours and maintain ties with the United States of America (USA) and china among other countries in the world. His shuttle diplomacy was referred to as "Jet setting president". He spent a quarter of his first 100 days in office in different countries. The oversea trips of Buhari led to the repatriation of money looted by Nigerians, Daizani former minister of Petroleum under President Goodluck Jonathan, James Ibori former governor of Delta state to mention but a few. Bello,I.,Dutse, A.I. \& Othman, M.F. (2017), President Obasanjo administration and Buhari's administration are similar in terms of travels to redeem the nation's image abroad but different in operations, Obasanjo anchored his shuttle diplomacy on debt cancellation to raise the standard of life of the citizens and improve the economy of the country. While Buhari travels is to improve relations with his neighbours and America to fight Boko Haram terrorism that was made incapacitated by the previous administration before 2015 Election. 
How did the democratic administration of Obasanjo and Buhari economic diplomacy impacted on citizens of Nigeria?

President Obasanjo emerged in the Nigerian political scene with the daunting task of resuscitating international image of the country. Nigeria has since the return to democracy in May 1999 focused on developing strategic partnerships with traditional and emerging global powers, to support its domestic priorities, on regional economic integration front, Nigeria under Obasanjo moved on the West African Gas pipeline project (WAPCO) that had been billed to facilitate the supply of natural gas to four countries in West Africa, Benin Republic, Ghana, Togo and CoteD’Ivoire. Obasanjo administration focused on improving the nation's economy, he encouraged foreign direct investment leading to investors from Idia, China, South Korea to invest in Nigeria, thereby giving jobs to the youths and reducing the rate of unemployment. He has cordial relations with his neighbours and encourages free trade market with other economic countries of West Africa (ECOWAS). Obasanjo trade liberalization improved the nation's economy by reducing import duty tax on essential commodities like wheat, and the coming of the mobile telephone boost small scale businesses and communication industry. Like Obasanjo, Buhari administration also focused on economic diplomacy especially on the agricultural sector President Buhari requested Obama administration to assist the government in curtailing corruption which has continued to plague the country, also seek the assistance of government towards improving the economy which included reforms in the energy sector by stopping oil theft. The meeting was followed up by a meeting with Vice president Joe Biden where it was agreed that the USA would assist Nigeria to root out corruption, ensure stability in the economy and also the policy with special reference to the Northern region of Nigeria which is the heart beat of the Boko Haram insurgency. Blanchard, L.P \& Husted, T.F (2016). Under the administration of Donald Trump, nothing seems to have changed, a US department of Justice recently filed a civil complain for the forfeiture of money (\$144 million) which are from corrupt proceeds by former Nigeria minister of Petroleum Drezani. Trump also demonstrated efforts to aid Buhari administration in his fight against Boko Haram with the proposed sales of military equipment to Nigeria, which included 12 ember A-29 super Tucano aircraft. The proposed arms sell also got the approval of senate in US congress who had earlier blocked the sales on the ground of Nigeria militaries having cases of human right abuse, Gional, F. (2017). Comparing Obasanjo and Buhari economic diplomacy they are similar, but with differences, Obasanjo Economic diplomacy for Nigeria and its agains are physical, the standard of living, military abuse of human right was low compared to that of Buhari. Under Buhari, human right abuses are growing by the day leading to insecurity in all parts of the country, \#EndSars, where innocent citizens were brutally murdered, the Nigeria naira is highly devaluated in Buhari administration and 90 percent of Nigeria citizens now leave from hand to mouth in abject poverty.

Has the administration of Obasanjo and Buhari leadership style have any influence on national interest of the country?

A country's foreign policy, also called foreign relations consists of self- interest strategies chosen by the state to safeguard its national interests and to achieve goals within its international relations milieu. Foreign policy of a country would have the following key components: i. Goals such as internal development of the country, maintenance of peace, territorial Expansion or Even ideological ones, ii. Priorities-some principles would be more 
important than other, iii. Time frame- priorities and goals may change with time, iv. Formality-foreign policy originate from a government or a formal set-up foreign policy and national interest are twin concepts in the realm of international relations, thus a sound interest foreign policy is a product of national interest. National interest as a concept can be traced back to Italy in the 16th and 17th centuries England. In America, its use by states men began establishment of the constitution. (http://flectcher tufts.edu/research/2004/shembilku-rozeta.pdf). In essence, constructive and beneficial foreign policy direction of the Obasanjo administration was intended to address and redress the perceived in adequacy inherent in "concentricism which was not at all an objective but a means; it was more or less a foreign policy tactic that had not been fully taken advantage of, and as a means to an end, concentricism had no focus” Akinterinwa, B.A. (2004). Consequently, President Obasanjo left no one in doubt about the thrust of his foreign policy and his intention to return Nigeria to the centre stage of Regional and global politics. His leadership style and personality meeting with Nigeria community in Diaspora, encouraging them to invest at home and making them part of his government attracted both multinational corporations, business interest and meeting Nigeria communities in the countries he visited.

President Buhari's approach is similar to that of Obasanjo, his visit to other countries gave Nigerians in diaspora confidence especially his purported fight against corruption, to revamp the nation's Economy, fight against insurgency especially the Boko Haram Terrorist sect that had lay seige to the North East of the country. His personality made the Arab world to open relationship with Nigeria, thereby giving loans with low interest rate for infrastructural development. The difference between the Obasanjo and Buhari's administration on Domestic Diplomacy is that Obasanjo vibrant approach to win investors to Nigeria is different from that of Buhari slow approach to issues of national interest which earn him a slogan "Baba go slow”. The above discussions, one can find out that Obasanjo's administration, Nigeria battered relations internationally have been taken to greater heights with improvement in bilateral economic and diplomatic drive. His administration promote greatly Africa total democratization, it secured an investment promotion and protection agreement with Germany, a trade pact with India and renewed the faith of foreign investors as expressed by the several trade and investment delegations to Nigeria from Japan, China, India U.S.A., Canada, UK, South African, Denmark, Ghana, Turkey, France, Belgium (Abdulai, 2007:17) Greece, Russia, Norway, Poland, Spain, Italy, Switzerland and Isreal also established bilateral investment relations with Nigeria during the Obasanjo Civilian administration (NIPC annual report, 2006, CBN draft annual report 2008). Buhari's administration 2015 till date hinged on his three cardinal points which include, combating terrorism, fighting corruption and improving on the economy. He had several relations from his travels, economics investment by china, diplomatic relations with China leading to the provision of loan to the tune of 2 billion dollars to Dangote cement factories Tanimu, A.M .T (2016). A part from economic relation between both countries, the countries also enjoy good diplomatic relations. China recently stated its support for Nigeria's quest for a permanent seat in the United Nations Security Council, Chinese parliament speaker Zhang Dejiang made this known during a meeting with his Nigerian counterpart Yakubu Dogara, this was part of effort to reform the United Nations (UN) and accommodate countries from another region. Buhari's slow approach to national issue had 
led to incompetent handling of his three point agenda there by increasing the risk of foreigner and citizens living in Nigeria.

\section{Summary, conclusion and recommendations}

\section{Summary}

Undoubtedly, Nigeria capabilities inform its role in international politics. Its ability to achieve its foreign objectives flow from how it assembles its variable capabilities. In a situation where the foreign vision and its assumed role impact negatively on its domestic affairs, its foreign objectives must be re-examined and refocused. A country's commitment to its foreign policy objectives and to articulate a set of desired gains achievable across her international boundaries for national interest or a desired role in international politics, this was what these two administrations of Obasanjo and Buhari set to achieve, their leadership role was identified with some challenges, domestic problem, rise in level of poverty, unemployment, illiteracy, dependent on mono-economy (oil), over borrowing, devaluation of the naira, corruption and insecurity. However, the researcher stressed that Nigeria foreign policy should be to achieve national interest, national welfare and national prestige.

\section{Conclusion}

This paper examines foreign policy under President Obasanjo civilian administration. It was able to transform Nigeria from isolated state of Abacha's regime to a globalized nation; the administration has also attracted foreign development investment in multiple ways especially in the area of oil and telecommunication. Comparing the Obasanjo administration foreign policy implementation, while that of Buhari civilian administration maintained good relationship with its neighbours to fight Boko Haram insurgency and also improved bilateral relations with China to cater for countries economic imbalance and also maintained good relations with United States of America.

\section{Recommendation}

Foreign policies are not forged in vacum, Nigeria's ability to influence the continent of Africa depends on how she is able to combine both internal and external variables. For Nigeria to successfully realize its foreign policy objectives, she must undergo a revolution in social national economic resources which have not been harnessed, the development of her economic base is absolutely necessary to maintain effective and consistent leadership, Nigerian's commitment in her foreign policies equal its capabilities with stable-polity and visionary leader.

\section{References:}

1. Abdul, S \&Ibrahim, M (2013), Interrogating, Nigeria's Foreing policy in the 21st Century Reflections on the Gains and challenges of Obasanjo’s administration 1999-2007.BassyAndoh Journal, 6, 31-51.

https://academicexcellencesociety.com/interrogating_nigeria\%E2\%80\%99s_foreign_policy_in_the_21st_c entury.pdf 
2. Agbu, O. (2009), Nigeria foreign policy under president Umaru Musa Yar'Adua: Challenges and prospect. In O. Eze(ed), citizen diplomacy. Victoria Island: The Nigeria Institute of International Affair, 4162.

3. Abdulai, D.N (2007), Attracting Foreign Direct Investment for Growth and Development in SubSahara Africa: Policy and Strategic alternatives. African Development, Vol. XXX II, No 2.

4. Akinterinwa,B.A (2004), concertricism in Nigeria foreign policy.Akinterinwa (ed) Nigeria's new foreign policy thrust:essay's in honour of ambassador OluyemiAdeniji, Ibadan vantage publishers.

5. Asobie, A (2002), Nigeria: Economic Diplomacy and National Interest an Analysis of the Polices of Nigeria Internal Economic Relations. Nigeria Institute of international Affairs Frankad Publisher.

6. Bello, Dutse, A.I and Othman, M.F. (2017), Comparative analysis of Nigeria foreign policy under Muhammadu Buhari Administration. Asia Pecific Journal of Education, Arts and Social Sciences. Vol. 4, No.4, 43-52. https://www.researchgate.net/profile/Ismail-Bello5/publication/321018477_Comparative_Analysis_of_Nigeria_Foreign_Policy_Under_Muhammadu_Buhar i_Administration_1983-1985_and_2015-2017/links/5a0860a0aca272ed279fb57c/Comparative-Analysis-ofNigeria-Foreign-Policy-Under-Muhammadu-Buhari-Administration-1983-1985-and-2015-2017.pdf

7. Blanchard, L.P \& Husted, T.F. (2016), Nigeria Current issues and US. Policy.congressional research services.

8. Bojang, A.S. (2018), The study of foreign policy in International Relations, Journal of Political Science and Public Affairs. https://www.everycrsreport.com/files/20141105_RL33964_7e7c33cf73cc09374c99d453ed9e7aec531301ee .pdf

9. Campbell, J. (2017), The U.S justice department and kleptocracy in Nigeria.retrieved from https:goo.gl//puappw

10. Constitution of the Federal Republic of Nigeria \& Fundamental Rights (Promugation) 1999

11. CBN (2002), Annual report and statement of account. Central Bank of Nigeria

12. Chibundu, V.N. (2009) foreign policy with particular reference to Nigeria (1961-2008) Ibadan spectrum Books limited.

13. Compbell, D. and Stanley,J (1963), Experimental and quasi-experimental designs for research. Chicago. IL: Rand-MC Nally..Drazner, D.W. (1999), The Sanltion Paradox: Economic statecraft and international relations. New York: Cambridge University press.

14. Ezeife, D.I (2003), The frenzied search for foreign Investors. A severly flawed policy. Called from.www.nigeria.world.com. International Journal of Advanced research in management and social sciences. ISSN: 2278-6236, Vol. 1 (No. 6) www.garph.co.uk (JARMASS (16).

15. Fawole, W.A. (2004), Understand Nigeria’s foreign policy under certain rule since 1999 institution, structure, processes \& performance. Ibadan college press.

16. Fey, M \& Ramsay, K.W. (2010), When is shuttle diplomacy worth the commute: Information sharing through mediation work in progress document. Retrieved 2016, https://www/rochester.edu/college/faculty/markfey/papers/mediatio.n3.2.pdf.

17. Gional, F. (2017), Nigeria war on Boko Haram gets US armament boost. African conflict monitor 2017.

18. Holsti, K.J. (1992), International politics: A framework for analysis. Englewood Cliffs, New Jersey: Prentice Hall Inc. Pp 168-70.

19. Keohane RO (1984), After hegemony: Cooperation and Discord in the world Economy. Princton, NJ; Princeton University Press.

20. Kings; M.C. (1998), Basic currents of Nigeria foreign policy, Washington Harvard University Press.

21. Morganthau, H. (1966) Politics among notions. Alfred Khoph, 1966 P 339.

22. Modelski, g. (1962) The Theory of Foreign Policy London. London University Press

23. NIPE \& CBN Annual report 2006 and 2008

24. Northedge, F.S (ed)(1974), The use of force in international relations: Studies of international politics.London faber and faber, 1974.pp,258.

25. Obasanjo, O. (1999), Inaugural speech at the eagle square. Abuja.

26. Ofosa, G. (2014), Nigeria Image reached all-time low during Abacha’s regime. Daily Independence.

27. Olasupo, O. (2015), Nigeria foreign Policy in the fourth republic: an assessment of the Impact of

28. Olusegun Obasanjo's Civilian administration's foreign policy (1999-2007). Peack Journal of social Sciences and Humanities vol. 3(5). Pp. 58-63. https://www.peackjournals.org/sub-journal-PJSSH.html 
29. Osagie, J. (2007), Nigeria: re-positioning Nigeria in the global arena. Lagos: Daily Champion.

30. Robert Axelrod, (1984), The Evolution of cooperation. New York:Basic Books,

31. Saliu, H.A (2007), Nigeria external image under Obasanjo. in H.A.Salui (ed), essays on contemporary Nigeria foreign policy (vol. 11.pp.243-262) Ibadan vantage publishers limited.

32. Sanubi, F.A. \& Oke, C.I.A (2017). Diplomatic shuttles in foreign policy: Were Obasanjo trips during his tenure of any Benefits to Nigeria Journal of Social and management science. Vol.12. No.1 https://www.academia.edu/41232278/DIPLOMATIC_SHUTTLES_IN_FOREIGN_POLICY_WERE_OB ASANJOS_TRIPS_DURING_HIS_TENURE_OF_ANY_BENEFITS_TO_NIGERIA

33. Tanimu, A.M.T (2016), New agreement and MOU between Nigeria and China to be signed as Bahari visits China. Retrieved from http://www.ng/news/investment/20160410-new agreement and mou between-nigeria and china

34. Ukwuije, C. (2015), Reflections on Nigeria Foreign Policy Posture under Musa Yar'Adua and Goodluck Jonathan on National progress and International Relations. International Policy Brief Services, 5(1), 109-118.

35. Wallace, W. (1971), Foreign policy and the political process, London: Macmillian. Creative Commons Attribution - Non Commercial - No Derivatives 4.0 International License. 